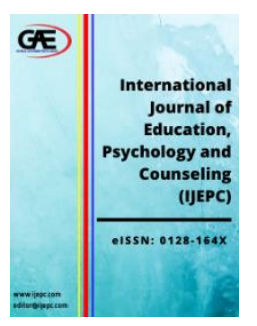

International Journal of Education, Psychology and Counselling (IJEPC)

Journal Website: http://ijepc.com/ eISSN: 0128-164X

\title{
THE USE OF PREPOSITIONS IN ARABIC AND ENGLISH: A COMPARATIVE STUDY
}

\author{
Emad Abedalaziz Alwreikat ${ }^{1}$, Assoc. Prof. Dr. Kamariah Yunus ${ }^{2}$ \\ 1 Faculty of Languages and Communications, Universiti Sultan Zainal Abidin, Malaysia \\ Email: emadwrikat@yahoo.com \\ 2 Faculty of Languages and Communications, Universiti Sultan Zainal Abidin, Malaysia \\ Email: kamariah@unisza.edu.my
}

\section{Article Info:}

Article history:

Received date: 23.02 .2020

Revised date: 15.03 .2020

Accepted date: 12.04 .2020

Published date: 05.06.2020

\section{To cite this document:}

Alwreikat, E. A., \& Yunus, K. (2020). The Use of Propositions in Arabic and English: A Comparative Study. International Journal of Education, Psychology and Counseling, 5 (35), 31-37.

DOI: $10.35631 /$ IJEPC.535004.

\begin{abstract}
:
Arabic and English are derived from different language families. While Arabic belongs to the Semitic family, English belongs to Germanic languages (Alhaj, 2015). Consequently, these two languages are supposed to have dissimilar prepositional structures. The methodology used in this study to comprehend these variances and resemblances regarding prepositions in Arabic and English, the researcher conducted a comparative study among these two prepositional systems. The objective of this paper is not to prove or disprove this claim. Its main focus is finding out how this syntactic feature is dealt with in English and Arabic in general and the contrast in the use of prepositions in both languages. To achieve this aim, the research makes use of the English categories of prepositions and gives the Arabic equivalents, in some cases, there is no Arabic equivalent because English prepositions are more than Arabic ones.
\end{abstract}

Keywords:

Prepositions, Arabic, English, Comparative Study

\section{Introduction}

Prepositions are a syntactic feature that is employed in writing in both English and Arabic. It is often argued, however, that the two languages differ in their use and number of prepositions. English, it is said, makes use of more prepositions, while Arabic favors the use of fewer prepositions (Al-Marrani, 2009).

This study main motivation is to find out how this feature is commonly used in Arabic and English and the differences in the practice of prepositions in both languages. In accomplishing this purpose, this study uses the English classes of prepositions and gives its Arabic counterparts. 
The reason behind this is that the researcher wants to get to a generalization about the hypothesis above, whether it is proven valid or not. In other words, by varying the equivalents and the different use of prepositions in both languages the researcher wants to get to general observations from which several researches could be triggered.

For the purpose of this study, the researcher contrasted prepositions usage in both languages, and the outcomes were matched to identify whether they are comparable or dissimilar.

\section{Literature Review}

The Literature has a plethora of research conducted on English and Arabic prepositions; these studies investigated the use of prepositions in the written text. This was revealed in many studies (Jin,1982; Bing Hiong ,2004; Simon Garrod ,1999; Eric Haeberli, 2005; Richard Ingham, 2005; Jenny Doetjec, 2006; Joao Costa, 2003; Janne Bondi, 2003; Thomas Ernst, 2006; Andrea Tyler, 2005, Stacy L.Klingler, 2005; Jia-Jiunn Loa, 2003; Ian Pratt-Hartmann, 2003; Karen Froud, 2000; David Kemmerer, 2004; Cynthia Fisher ;Loe Hoye 1997; ShiouWen Yeh, 2003; Al-Marrani , 2009; Aldahesh, 2013; Saeed, 2014; Alayesh, 2012; Alhawary, 2011; Alhaj, 2015).

According to (Jin, 1982., Lindstromberg, 2010), English Language prepositions possess multiple meanings, and many prepositions are so complicated that require much memory work from the learners. The prepositions reflect functional or physical relations between objects in the world (Simon Garrod, Gillan Ferrier, Siobhan Campbell 1999). However, Prepositions seem to encode relationships between objects, times, places or grammatical entities (Karen Froud, 2000).

\section{Preposition in English}

A preposition is one of the eight parts of speech. Specifically, a preposition is a connector: its function is to connect a noun or pronoun (called the object of the preposition) to another word in a sentence Vas (2006).

It also shows how that noun or pronoun (its object) is related to the other word. Consequently, a preposition can never stand alone: it must always be contained within a phrase (a group of words) called a prepositional phrase. Most often, prepositions show relationships of direction, location, and time, but they can also express other relationships as well (for example, the prepositions, but, except, without, etc. show a relationship of exclusion) (Celentano, 2008; Cossé, 2005).

\section{Commonly Used Prepositions}

Above, behind, for, since, about, below, from, to, across, beneath, in, toward, after, beside, inside, though, against, between, into, under, along, beyond, like, until, among, by, near, up, around, down, of, upon, at, during, off, with, before, except, on, within. (Grubic, 2004; Macková, 2012)

Let's look at how prepositions show a relationship to a word in the rest of the sentence.

- Rama likes to eat on the garden wooden table.

"On the garden wooden table" is the prepositional phrase. It is a modifier that tells us where Mary likes to eat. It is modifying the verb "to eat."

Examples of Prepositional Phrases:

1. Halla fell on the ground. (direction) 
2. Aziz travelled after his nineteenth birthday. (time)

3. Njood is walking near her daughter. (location)

4. Abood finished the test less than an hour. (time)

Sometimes prepositions occur as combinations. The following examples are some of the more common of these compound prepositions:

Ahead of, apart from, as a consequence of, because of, on behalf of, in advance of, instead of, in addition to, in the course of, regardless of, in care of, in comparison with, according to, in case of, for fear of, next to, in favor of, with the exception of, up against, at the risk of, along with, in spite of, in connection with, together with, as a result of (Grubic , 2004).

Examples of compound prepositions

1. As a result of the depression, we had to move out to the city.

2. Instead of visiting the zoo this weekend, we are going to Petra.

\section{Prepositions in Arabic}

Prepositions in Arabic are used just like in English (Zughoul, 1973); they come before the noun, around the house = hawla al bait (around = hawla). In front of the house = amama al bait $($ amama $=$ in front of) (Alhaj, 2015). Some prepositions that are one word in English may contain two words in Arabic, for example (among = men bayn) which means literally "from between". And vice versa, some Arabic one word may be the equivalent of a compound English preposition, like: in front of = fawka (Salim, 2006; Saeed, 2014).

Furthermore, Arabic prepositions are not as much of in number as their English equivalents (Al-Marrani, 2009). English language encompasses around one hundred prepositions (Leacock et al, 2014) while, the number of prepositions in Arabic is around twenty (Alhawary, 2011)

\section{Methodology}

The methodology the researcher used in this study is a comparative analysis of the Arabic and English prepositions, the researcher presents at first the definitions of both languages, and then the researcher gives the categories of the Arabic prepositions and after that, he gives their equivalents in the English language.

A comparison can be made between both languages by analyzing each language prepositions in term of their definition, categories, usage, and their position in the sentence. The differences and similarities between the two languages are shown in the examples that demonstrate the conclusion of this study.

\section{Analysis}

Table1: English Prepositions and Their Arabic Equivalents

\begin{tabular}{|l|l|}
\hline \multicolumn{2}{|c|}{ English and Arabic Prepositions } \\
\hline About: hawla & in spite of: berraghmi men \\
\hline Above: fawqa & Including: mo'taberan \\
\hline according to: wafqan li & Inside: beddakhel \\
\hline Across: 'abra & instead of: 'ewadan 'an \\
\hline After: ba'da & Less: aqal \\
\hline Against: dedda & Like: methla (or) ka \\
\hline ahead of: amama & Minus: naqes \\
\hline
\end{tabular}




\begin{tabular}{|l|l|} 
all over: men jaded & Near: qareeb \\
\hline Along: 'ala tool & near to: qareeb men \\
\hline Among: men bayn & next to: bejaneb \\
\hline Around: hawla & Of: men (not for possessive) \\
\hline As: ka & On: 'ala \\
\hline As ... as: ka & on top of: fawqa \\
\hline Aside: bejaaneb & Opposite to: 'aksa \\
\hline At: 'ala & Out: khaarej \\
\hline away from: ba'eedan 'an & Outside: bel kharej men \\
\hline because of: besababi & Over: 'ala \\
\hline Before: qabla & Per: li kolli \\
\hline Behind: waraa' & Plus: idafatan ila \\
\hline Below: tahta & Regarding: bekhosoos \\
\hline Beneath: men taht & Save: bestithnaa' (th as in think) \\
\hline Beside: bejaneb & similar to: moshaabeh li \\
\hline Besides: bel idafati ila & Since: mundu \\
\hline Between: bayna & Than: men \\
\hline Beyond: wara'a & thanks to: befadli \\
\hline But: laken & Through: khelaala \\
\hline By: 'ala & Till: ila (or) ila ghaayat \\
\hline close by: bel qurbi men & To: ila \\
\hline close to: bejaneb & Towards: bettejaah \\
\hline Concerning: bekhosoos & Under: tahta \\
\hline Despite: raghma & Unlike: kheelafan 'an \\
\hline Down: tahta & Until: ila ghayet \\
\hline due to: naatej 'an & Up: fawq \\
\hline During: khelaala & Versus: 'aaksa \\
\hline except for: bestethnaa' & Via: 'abra \\
\hline Excluding: mostathnian & With: ma'a \\
\hline for: li & Without: bedoon \\
\hline From: men & Neither ... nor: laa ..... wala \\
\hline In: fi & When (not for question): 'endamaa \\
\hline in front of: amama & Whenever: kullamaa \\
\hline in place of: makana & Wherever: haithumaa (th as in think) \\
\hline As if: kamaa law & If: ithaa (th as in this) \\
\hline Either: imma or aw & \\
\hline
\end{tabular}

Table2: Arabic Demonstrative Prepositions

\begin{tabular}{|l|}
\hline This = used for masculine: hatha (th as in them) \\
\hline This = used for feminine: hatheh (th as in them) \\
\hline That = used for masculine: $\underline{\text { thalek (th as in them) }}$ \\
\hline That = used for feminine: tilka \\
\hline These = ha'ola' \\
\hline Those = ola'ek \\
\hline
\end{tabular}


Table3: The Main Categories Of Prepositions In Both Languages

\begin{tabular}{|c|c|c|}
\hline The category & English & Arabic \\
\hline Position & In, on, at & في عن، على, بـ،, \\
\hline Destination & To, on, into & لعلى، إلى في، \\
\hline Neg. Position & Off, away from & من من \\
\hline Relative Position & Over, under, etc. & تحت فوق، \\
\hline Relative Destination & Over, under, & خلف فوق, تحت, \\
\hline Passage & Across, on, in & عبر على، في، \\
\hline Reference & Along, across & مع، عبر \\
\hline Orientation & Beyond, over & فوق، ور اء \\
\hline Resultative & Over, out of & وراء فوق، \\
\hline Pervasive & All over & في \\
\hline Time when & at, on, in & في \\
\hline Duration & For, from...to & إلى ... منذ، من \\
\hline Point relation & Before, after, & قبل، بعد، منذ \\
\hline Cause purpose & For & من من \\
\hline Source origin & From & بـ5 \\
\hline Means instrument & By, with, without & بلا بـ, \\
\hline Agentive & By & \\
\hline Alarm & At & \lrcorner \\
\hline Accompaniment & With & مع , بـ، \\
\hline Modifiers agentive & Of & \\
\hline Possession & Of, with, without & \\
\hline Concession & In spite of, & على \\
\hline Reference & With regard to, as & \\
\hline Exception & Except for, & حدا ما ما خلا، ماعدا، \\
\hline Neg. condition & But for & \\
\hline Subject matter & On, about & في على، عن، \\
\hline Ingredient & Of, with & ل \\
\hline Respect & At & في \\
\hline Reaction & At, to & لـ لـ على ، \\
\hline
\end{tabular}

\section{Conclusion}

Through the contrasting of prepositions above in both languages, we conclude many things like:

1. The number of English prepositions is more than Arabic ones.

2. In English language, the Prepositions are always free morphemes but In Arabic it sometimes comes as an affixes (prefix) attached to the noun that follows it like in the examples:

Jehad bought a car for his son wajed 'Eshtara Jehad siarah le'ebneh wajed

3. In some cases, English prepositions does not have an equivalent. This means that Arabic expresses this sense not by means of prepositions, but by other means that are contextually determined, like the English prepositions: Neg. condition preposition (But for), Reference preposition (With regard to, as to), Possession preposition (Of, with, without), Modifiers agentive (of), Agentive ( By), and we can see this in the examples: 
The hand of the door Months of the year albab

'ashhor alsana'

4. Some Arabic prepositions have more than one meaning like the preposition في (Fii) and it has many meanings like: At, On, All over, To...

5. Sometimes, the meaning of the preposition differs between Arabic and English according to its meaning like in the examples:
Mohammad arrived on time Mohammad Wasala fii alme'aad
Qutaiba put the keys on the table
Qutaiba wada'a almfateeh 'ala altawilah

6. Sometimes the meaning of the preposition differs in the same language like in English the following examples sows that:

This interview is about world economics

Hadihi almoqabala haola al'eqtesad al'alami

I reached home yesterday about ten

Ana wasalto ala albaite Albarehah alsa'aa al'asherah taqreeban

7. In both languages the preposition doesn't have a dependent meaning and it can't stand alone.

8. In English language, the pronoun that follows the preposition must be in the object state like the example:

Shadi offered the present to him

9. Some English prepositions have various states when translated into Arabic such As the English preposition "Of" like in the following examples:

Aziz drove in the streets of Amman

Aziz saq Fii shoare' Amman

Abood bought two cups of coffee

Abood eshtra kobaeene Min alqahoa

The file of the radio is burnt

Mohawel alradio mahrooq

10. The semantic relations are notoriously difficult to restrict in a defined way, and any attempt to do justice even to the main sense of prepositions will require a detailed study, which falls outside the scope of the study.

\section{References}

Alhaj, A. 2015. The Ambit of English\Arabic Translation: A Practical and Theoretical Guide for English\Arabic Translator. Anchor Academic Publishing.

Al-Marrani, Y. 2009. "A Comparative and Contrastive Study of Preposition in Arabic and English". Language in India. Vol 9.

Alhawary, M. 2011. Modern Standard Arabic Grammar: Learneres guide. UK: WileyBlackwell. p,126.

Andrea Tyler (2005). The semantics of English Prepositions (Science directory) 
Celentano, T. 2008. Mastering English prepositions for ESL learners: Using them correctly in every English sentence. Kailua. Hawaii. 96734.

Cossé, L. 2005. My Communicative Grammar: Study Guide. Venezuela: University of Carabobo.

David Kemmerer (2004). The spatial and temporal meanings of English prepositions can be independently impaired (Science directory)

Grubic, B. 2004. "Those Problematic English Prepositions!” CFI- Baci Conference Long Beach, California, p. 1-34.

Karen Froud (2000). Prepositions and the lexical, functional divide: Aphasic evidence (Science directory)

Leacock, C. Chodorow, M. Gamon, M and Tetreault, J. 2014. Automated Grammatical Error Detection for Language Learners. Morgan and Claypool publishers. P. 47.

Lindstromberg, S. 2010. English Prepositions Explained. Amsterdam, Netherland: John Benjamins.

Macková, L. 2012. “A Contrastive Analysis of the Prepositions To and Into”. Master Thesis. Masaryk University.

Saeed, S. 2014. "The Syntax and Semantics of Arabic Spatial Prepositions". Newcastle and Northumbria working papers in linguistics. Newcastle University.p.44-66.

Salim 2005-2006 speak7@ gmail.com

Vas, G. 2006. Prepositions: An Extensive Collection of Prepositions and Their Proper Usage. New Delhi: Sterling publishers Pvt Ltd.p. 1-2.

Zughoul, M. R. 1973. Teaching English prepositions to Arab students. Unpublished MA Thesis, American University of Beirut 